\title{
POLITIKK
}

SKANDINAVISK TIDSSKRIFT

FOR INTERNASJONALE STUDIER

Årgang 80, Nummer 1, side 78-103, 2022, ISSN 1891-1757, www.tidsskriftet-ip.no, Publisert februar 2022

\section{Legitimering mellom normer og interesser. Norges våpeneksport til land som kriger i Jemen}

\author{
Susanne Therese Hansen* \\ Norges teknisk-naturvitenskapelige universitet (NTNU), Norge
}

\begin{abstract}
Sammendrag
Norge er internasjonalt forpliktet til å avstå fra våpeneksport dersom det er overveiende sannsynlig at materiellet som eksporteres kan brukes i humanitærrettsbrudd. I tillegg har Norge nasjonale vedtak om å ikke eksportere våpen til krigende land uten at eksporten er sikkerhetspolitisk motivert, fortrinnsvis av alliansehensyn. Likevel vedvarte Norges eksport av militærmateriell til flere land i den Saudi-Arabia-ledede koalisjonen under krigen i Jemen; en koalisjon som har begått utallige humanitærrettsbrudd i Jemen, og som Norge eksporterer til på kommersielt grunnlag. Denne artikkelen undersøker hvordan norske myndigheter har legitimert våpeneksporten til land som kriger i Jemen. Artikkelen finner at legitimeringen er konstruert rundt fem dimensjoner, hvorav fire tar form som offentlig kommuniserte forsikringer om at norske myndigheter har full kontroll og følger regelverket. En femte dimensjon, bevisst utelatt og ikke-kommunisert av myndighetene, men synlig i lekkede kilder, omhandler bekymringer om at stans i eksporten kan skade forsvarsindustriens markedsmuligheter i regionen. Artikkelens konklusjon er todelt: For det første viser kombinasjonen av forsikringer og utelatelse at legitimeringen av eksporten til koalisjonslandene i stor grad er ment å berolige kritikere. For det andre viser innholdet i legitimeringen at eksporten hviler på en tidvis feilaktig fortolkning av retningslinjene for våpeneksporten.
\end{abstract}

Nøkkelord: legitimering • våpeneksport • normer • forsvarsindustri • humanitæretten

\footnotetext{
^Kontaktinformasjon: Susanne Therese Hansen, e-post: susanne.hansen@samforsk.no

(C)2022 Susanne Therese Hansen. This is an Open Access article distributed under the terms of the Creative Commons Attribution 4.0 International License (https://creativecommons.org/licenses/BY/4.0/), allowing third parties to copy and redistribute the material in any medium or format and to remix, transform, and build upon the material for any purpose, even commercially, provided the original work is properly cited and states its license.

Citation: Hansen, S. T. (2022). Legitimering mellom normer og interesser. Norges våpeneksport til land som kriger $i$ femen. Internasjonal Politikk, 80(1), 78-103. http://dx.doi.org/10.23865/intpol.v80.3271
} 


\section{Innledning}

26. mars 2015 startet en militær intervensjon av Jemen, anført av en koalisjon ledet av Saudi-Arabia. ${ }^{1}$ Koalisjonen besvarte Jemens president Abdrabbuh Mansur Hadis forespørsel om hjelp til å stanse houtienes opprørsbevegelse. Det internasjonale samfunn rettet raskt oppmerksomheten mot koalisjonens brudd på internasjonal humanitærrett - krigens folkerett - $i$ Jemen. Humanitærretten, spesielt prinsippet om humanitære hensyn, forbyr angrep på sivile mål der angrepene ikke er nødvendige for å oppnå militære målsettinger. I Jemen hadde koalisjonens luftangrep rammet sivile mål som sykehus, boligområder, markeder, begravelser og bryllup i et omfang som tydet på at sivile i seg selv var et angrepsmål, og FN har gjentagende konkludert med at koalisjonen har brutt humanitærretten i Jemen (FNs ekspertpanel for Jemen, 2016, 2017, 2020). ${ }^{2}$ Til tross for koalisjonens merittliste i Jemen, har land i koalisjonen i løpet av krigen i Jemen fått importere store mengder militært materiell fra vestlige land, også fra Norge. FNs ekspertgruppe for Jemen har bedt landene som bevæpner koalisjonen om å stanse eksporten som muliggiør krigføringen. Ifølge ekspertgruppen medvirker eksportørene til humanitærrettsbrudd i Jemen og bryter internasjonale avtaleverk for våpeneksporten (FNs ekspertpanel for Jemen, 2020).

I Norge har eksporten av militærmateriell til land i koalisjonen resultert i en uvanlig langvarig debatt om norsk våpeneksport. Norge er tilsluttet internasjonale avtaler som forbyr eksport dersom det er overveiende sannsynlig at materiellet kan bli brukt i humanitærrettsbrudd. Norge har dessuten nasjonalt vedtatt (i det såkalte "1959-vedtaket») å ikke eksportere til stater i krig; et vedtak som frem til krigen i Jemen utelukket eksport til krigende land det ikke forelå sikkerhetspolitiske grunner for eksport til. Eksporten til koalisjonslandene har i offentligheten blitt møtt med kritikk på både juridisk og moralsk grunnlag, Riksrevisjonen har levert en knusende rapport om håndhevingen av retningslinjene for eksportkontrollen, og flere ganger har regjeringen måttet redegjøre for eksporten i Stortinget. Den angivelig mest graverende delen av eksporten ble stanset noen år ut i krigen, men fortsatt eksporteres militærmateriell til land i koalisjonen.

Denne artikkelen søker å forklare hvordan norske myndigheter, ved to påfølgende regjeringer (begge ledet av statsminister Erna Solberg) og Utenriksdepartementet, i perioden 2015-2021 har legitimert våpeneksporten til land som kriger i Jemen. Dette gjøres ved å beskrive og analysere de språklige legitimeringsstrategiene som ansvarlige myndigheter har mobilisert når de har forsvart eksporten til koalisjonslandene overfor offentligheten. Fordi mye av kritikken omhandler påstand om

\footnotetext{
${ }^{1}$ Koalisjonen bestod også av Egypt, Marokko, Jordan, Sudan, De forente arabiske emirater, Kuwait, Bahrain og Qatar. Qatar forlot koalisjonen i 2017.

${ }^{2}$ Humanitærrettsbruddene foregikk også gjennom en blokade som har medført mangel på mat og medisiner og forårsaket en alvorlig humanitær katastrofe i det allerede fattige landet (FNs ekspertpanel for Jemen, 2019).
} 


\section{Susanne Therese Hansen}

regelverksbrudd, diskuteres også legitimeringen opp mot regelverket. Artikkelen drar i tillegg noen paralleller mellom Norges og andre lands legitimeringsstrategier.

Politiske legitimeringsstrategier er språkhandlinger ment å forsvare politiske beslutninger. Gjennom studier av legitimeringsstrategier kan man si noe om myndighetenes intensjon der intensjonen ikke er eksplisitt uttrykt. Å slutte fra språkhandlinger til intensjoner kan ha metodiske begrensninger ved at intensjonene forskeren tillegger myndighetene ikke fullt ut gjenspeiler virkeligheten. Slike metodiske begrensninger kompenseres her ved nøye refleksjon rundt egen vurdering av datagrunnlaget (Schedler, 2012), og god kildedokumentasjon for å sikre etterprøvbarhet.

Våpeneksporten er underlagt betydelig hemmelighold. Eksportstatistikk publiseres årlig i regjeringens stortingsmeldinger, men statistikkens aggregeringsnivå er høyt. Informasjon om vurderingene bak eksportbeslutningene når dessuten ikke offentligheten, annet enn bruddvis i saker hvor myndighetene tvinges til kritikkhåndtering. Denne artikkelen omhandler en slik sak. Artikkelen baserer seg på alt offentlig tilgjengelig materiale om myndighetenes eksportvurderinger, hovedsakelig innhentet fra stortingsmeldinger, stortingsdebatter og pressemeldinger. En rapport utgitt av Riksrevisjonen i februar 2021, som vurderte myndighetenes regelverksanvendelse i våpeneksporten, spiller også en informativ rolle. Deler av rapporten, et vedlegg som omtaler vurderinger bak eksporten til Emiratene, ble av regjeringen unntatt offentlighet etter sikkerhetsloven. Vedlegget har imidlertid blitt lekket til Aftenposten, som i mai 2021 gjenga deler av innholdet. Aftenpostens gjengivelser inngår i denne artikkelens kildegrunnlag. Videre er søkedatabasen Atekst Retriever benyttet for et bilde av medias fremstilling av saken. Utenriksdepartementets eksportkontrollseksjon har ikke vært villige til å besvare mine henvendelser vedrørende eksporten til koalisjonslandene, og henviser i personlig korrespondanse til stortingsmeldingene og utenriksministerens offentlige uttalelser (Eksportkontrollseksjonen, 2021). Det er ikke usannsynlig at departementets manglende vilje til å uttale seg kan tolkes i sammenheng med sakens sensitivitet.

Artikkelens struktur og argument er som følger: Først gis et innblikk i hva tidligere forskning sier om legitimering av våpeneksport. Videre presenteres Norges våpeneksport til koalisjonslandene, og debatten rundt eksporten, før oppmerksomheten rettes mot legitimeringen av eksporten. Konkret er myndighetenes legitimering konstruert rundt fem dimensjoner. Fire av disse er offentlig kommuniserte forsikringer om at alt er under kontroll og at myndighetene vet hva de gjør, blant annet fordi regelverket er bra. En femte dimensjon omhandler hensyn til forsvarsindustrien. Sistnevnte kommuniseres i hemmeligholdte dokumenter, og utelates fra myndighetenes offentlige beretning om eksporten. Artikkelens konklusjon er todelt: For det første viser kombinasjonen av forsikringer og utelatelse at legitimeringen av eksporten til koalisjonslandene i stor grad er ment å berolige kritikere. For det andre viser legitimeringen at eksporten til koalisjonslandene hviler på en tidvis feilaktig fortolkning av retningslinjene for våpeneksporten, inkludert 1959-vedtaket, angivelig selve bærebjelken i norsk våpeneksportkontroll. 


\section{Drivkrefter og legitimering}

Våpeneksporten har alltid vært drevet av, og av staters myndigheter i varierende grad legitimert på basis av, materielle forhold. En viktig materiell drivkraft for våpeneksporten ligger i dens bidrag til den nasjonale forsvarsindustriens overlevelse, og således til nasjonale forsvarspolitiske og sikkerhetspolitiske behov. En nasjonal forsvarsindustri har tradisjonelt vært ansett som en forutsetning for nasjonal sikkerhet, og motvirker usikkerhet rundt forsyningssikkerheten for nasjonale styrker i krisetid (Dorman et al., 2015). Å opprettholde en moderne, høyteknologisk forsvarsindustri koster imidlertid mye, og overproduksjon i fredstid lar seg vanskelig legitimere med mindre kostnaden spres. Eksport har i de fleste våpenproduserende land, Norge inkludert, derfor lenge vært et middel for å holde produksjonskostnadene nede, og således ivareta nasjonale forsvarsindustrier (Bitzinger, 1994, s. 173-174; Wicken, 1992, s. 111-112). Man har i Norge en eksplisitt, politisk formulert målsetting om å bruke våpeneksport som virkemiddel for å opprettholde en internasjonalt konkurransedyktig forsvarsindustri som kan bidra til leveringssikkerheten til Norges og alliertes forsvar. Målsettingen repeteres årlig i stortingsmeldingene om våpeneksporten, med påfølgende rutinepreget stortingstilslutning (e.g. Innst. 185 S (2015-2016); Innst. 81 S (2018-2019); Meld. St. 9 (2015-2016); Meld. St. 35 (2020-2021)). Det er i Norge bred politisk støtte til bruk av våpeneksport som forsvars- og sikkerhetspolitisk virkemiddel (Meld. St. 5 (2017-2018), s. 7).

En annen typisk begrunnelse når stater legitimerer våpeneksport, er et økonomisk argument om at forsvarsindustrien bidrar med profitt og arbeidsplasser (Dorman et al., 2015, s. 37-51). Eksempelvis ble Storbritannias kontroversielle våpensalg til Saudi-Arabia på 1980-tallet (Al Yamamah-avtalene) legitimert som et virkemiddel for å skape og ivareta arbeidsplasser, gjerne i små industrisamfunn (Wearing, 2016, s. 15). I Norge har det økonomiske motivet vært mindre eksplisitt betont, særlig om mottakeren er kontroversiell. De sterke reaksjonene som fulgte da statssekretær Roger Ingebrigtsen (Ap) under et besøk til våpenprodusenten Vinghøg AS hadde uttrykt at våpenindustrien kunne bidra til Norges overlevelse når oljen tar slutt (TU, 2011), illustrerer hvorfor det økonomiske motivet ofte nedtones: Å profitere på krig og opprustning anses i beste fall kontroversielt. Hensynet til industriarbeidsplasser har likevel stått sentralt i norsk våpeneksport; flere ganger i historien har man tatt en betydelig politisk-moralsk kostnad for at industrien skal tjene til livets opphold. ${ }^{3}$ Forsvarsindustriens generering av arbeidsplasser omtales også i stortingsmeldingene om eksportkontrollen (Meld. St. 35 (2020-2021), s. 8).

\footnotetext{
${ }^{3}$ Flere kontroversielle utførsler av ammunisjon har funnet sted etter påtrykk fra Raufoss Ammunisjonsfabrikker i perioder hvor lav etterspørsel tilsa oppsigelser og store konsekvenser for lokalsamfunnet. Eksempelvis tillot den norske regjering - til stor kritikk fra både det internasjonale samfunn og flere partier på Stortinget - utførsel av ammunisjon til krigsherjede Bolivia på 1930-tallet, og til Cuba på 1950-tallet (Hoel, 2017; Wicken, 1992, s. 18-38). Begge utførslene kom etter betydelig påtrykk fra industrien.
} 
Våpeneksport kan også legitimeres som et strategisk utenrikspolitisk virkemiddel for å svekke motstandere, styrke bånd med strategiske partnere, eller styrke allianser. USA brukte og legitimerte under den kalde krigen våpeneksport som et strategisk virkemiddel for å svekke kommunisme (Blanton, 2005), og senere for å belønne partnere i krigen mot terror (Stohl, 2008). I Storbritannia omtales forsvarsindustrien som et ledd i britenes utenrikspolitiske innflytelse (Dorman et al., 2015), og i Frankrike kobles forsvarsindustrien til grandeur (Béraud-Sudreau, 2018). Norge har ikke strategiske ambisjoner på linje med USA, Storbritannia og Frankrike, men det strategiske motivet - spesielt alliansehensyn - brukes likevel for å gi våpeneksporten politisk legitimitet. For Norges del er strategiske hensyn typisk drevet av sikkerhetspolitiske behov snarere enn søken etter innflytelse.

De materielle drivkreftene beskrevet over ${ }^{4}$ uttrykkes blant annet ved at land etablerer apparater for eksportfremming i strategisk viktige markeder (Béraud-Sudreau, 2018; Hansen \& Marsh, 2015). Den norske regjeringen har i flere år fremmet våpeneksport i Midtøsten, særlig til Emiratene (Egeland, 2019, s. 108). Symptomatisk nok etablerte halvt statseide $\mathrm{Nammo}^{5}$ i 2015 - samme året som krigen i Jemen startet - et salgskontor i Emiratene.

Parallelt med de materielle drivkreftene som fremmer våpeneksporten, ligger en moralsk drivkraft med lange historiske røtter, som motsatt etterstreber begrensninger på eksporten. I Norge har argumenter om at det er umoralsk å eksportere våpen og ammunisjon til krigsformål hatt stor giennomslagskraft, og er sporbare i nasjonale retningslinjer (Wicken, 1992, s. 6). Den angivelige bærebjelken i norske retningslinjer er det såkalte «1959-vedtaket» og en presisering fra 1997. 1959-vedtaket stadfester at «hovedsynspunktet bør være at Norge ikke vil tillate salg av våpen og ammunisjon til områder hvor det er krig eller krig truer, eller til land hvor det er borgerkrig» (Meld. St. 5 (2017-2018), s. 9). Stortingets presisering av 1997 supplerer at man også må vurdere "spørsmål knyttet til demokratiske rettigheter og respekt for grunnleggende menneskerettigheter (Meld. St. 25 (2019-2020), s. 17). Angivelig vektlegges også humanitærrettslige forhold (Meld. St. 5 (2017-2018), s. 9).

Internasjonalt uttrykkes forsøk på å begrense våpeneksporten i form av internasjonale avtaler som etablerer etiske standarder for handel med militært materiell. Viktigst for Norge er FNs våpeneksportkontrollavtale Arms Trade Treaty (ATT), og EUs felles posisjon for våpeneksportkontroll. ATT er den første globale, juridisk bindende avtalen for internasjonal våpeneksport, og trådte i kraft i desember 2014, tre måneder før koalisjonens intervensjon i Jemen. ATTs artikkel 7 forplikter stater til å vurdere mulige konsekvenser av eksporten for blant annet fred og sikkerhet, menneskerettighetsbrudd og humanitærrettsbrudd. Eksport skal ikke forekomme dersom det

\footnotetext{
${ }^{4}$ Gjennomgangen er ikke uttømmende. Nok en drivkraft for forsvarsindustriens overlevelse og dermed for våpeneksporten ligger $i$ at forsvarsindustrien kan bidra til teknologiutvikling og «spinoff» til sivil sektor.

${ }^{5}$ Tidligere Raufoss Ammunisjonsfabrikker inngår i Nammo.
} 
er overveiende sannsynlig («overriding risk») at materiellet kan anvendes i eksempelvis humanitærrettsbrudd ( $\mathrm{FN}, 2014)$. EUs felles posisjon for våpeneksportkontroll fra 2008 anmoder eksportører om å avstå fra eksport ved tydelig risiko ("clear risk») for at materiellet kan bli brukt i humanitærrettsbrudd eller aggressivt mot andre land, kan ha negativ innvirkning på regional stabilitet, eller kan videreeksporters til opprørsgrupper eller terrornettverk (Rådet for Den europeiske union, 2008). Begge avtalene, tatt inn i norske eksportkontrollretningslinjer før koalisjonen begynte sin krigføring i Jemen, fremmer en preventiv føre-var-tilnærming til våpeneksporten, tuftet på nøye vurdering av risiko vedrørende bruken av det eksporterte materiellet.

Mens eksport til allierte for Norges vedkommende kan begrunnes med sikkerhets- og alliansepolitiske interesser, kan ikke slike hensyn legges til grunn for eksporten til koalisjonslandene. Ikke er det sikkerhetspolitiske grunner til å forsyne disse landene med materiell, og landgruppens aktivitet i Jemen gjør eksporten for kontroversiell til at betoning av industriens begunstigelse, økonomisk gevinst og arbeidsplasser tar seg ut i offentligheten. Man må derfor forvente at norske myndigheter, i legitimeringen av eksporten til koalisjonslandene, trolig unngår en legitimering bygd på eksplisitte, materielle argumenter. Våpeneksporten må dessuten kunne legitimeres innenfor rammene av hva eksportretningslinjene tillater; legitimeringen må altså hensynta normer og regler, ikke bare materielle interesser. Det er imidlertid enklere å henvise til retningslinjene når man stanser enn når man viderefører kontroversielle utførsler. Jo mer kontroversiell eksporten som videreføres er, jo mer kan myndigheters legitimering forventes å måtte overbevise om at eksporten følger regelverket. Slike forsøk på overbevisning har man sett hos britiske myndigheter, som kom i en langvarig rettstvist da organisasjonen Campaign Against the Arms Trade saksøkte myndighetene for vedvarende våpeneksport til Saudi-Arabia under krigen i Jemen. Stavrianakis (2017, 2020) viser hvordan britiske myndigheter håndterer kritikk ved å repetere at det britiske regelverket er blant verdens strengeste, ved å benekte bevis for at Saudi-Arabia har brutt humanitærretten i Jemen, og ved å vektlegge lovnader fra Saudi-Arabia om at koalisjonen ikke med intensjon bryter humanitærretten i Jemen. I britenes kritikkhåndtering nedtones materielle motiver, og eksporten legitimeres ved å forsikre og benekte. Denne artikkelen identifiserer en lignende strategi hos norske myndigheter.

Empirisk står våpeneksporten mellom to motstridende drivkrefter: sterke eksportinteresser og restriktive eksportkontrollnormer. Teoretiske forventninger til internasjonale, restriktive forpliktelsers virkning i situasjoner med motstridende drivkrefter er i beste fall sprikende, og på våpeneksportkontrollfeltet pessimistiske. En nokså unison forskning beskriver hvordan forpliktelser innen våpeneksportkontrollen i praksis ofte brytes på grunn av eksportinteresser (Cooper, 2000; Erickson, 2013; Hansen \& Marsh, 2015; Johnson \&Williardson, 2018), samtidig som eksportlandene hevder å operere innenfor rammene av de kontrollregimer de er tilsluttet (Hansen, 2016). Norges fortsatte eksport til koalisjonslandene fremstår her som en normalitet. Riktignok er våpeneksportkontrollen tilskrevet en viss restriktiv virkning der sivile samfunnsaktører evner å øke den politiske kostnaden ved eksport 


\section{Susanne Therese Hansen}

via såkalt «shaming» (Erickson, 2015). «Shaming» - eller «skampåføring» på norsk innebærer at en aktør offentlig beskylder en annen aktør for å gjøre noe galt, ved å spille på misforholdet mellom politikken og den utøvende aktørens moral eller identitet (Markwica, 2018, s. 82; Snyder, 2020). I våpeneksporten kan skampåføring påvirke de politisk mest kontroversielle sakene, hvor myndighetene endrer kurs for å «redde ansikt» (Erickson, 2015). Konklusjonen returnerer til spørsmålet om hvorvidt myndighetenes legitimering vitner om at skampåføring har hatt betydning i Norge.

\section{Eksporten og debatten}

Lov om kontroll med eksport av strategiske varer, tjenester og teknologi m.v. av 18. desember 1987 (Eksportkontrolloven) med forskrift ${ }^{6}$ påfører lisensplikt for eksport av forsvarsmateriell og flerbruksvarer ${ }^{7}$ fra Norge. Dette innebærer at produsenter av slike varer, når de mottar forespørsler om eksport, må søke norske myndigheter ved Utenriksdepartementets eksportkontrollseksjon ${ }^{8}$ om utførselslisens. Vedtakene som gjøres i departementet må være i tråd med nasjonale og internasjonale retningslinjer, og gjøres også i henhold til en våpenkategorisering og en landgruppeinndeling. Norge differensierer mellom eksport av A-materiell, B-materiell og flerbruksmateriell. A-materiell dekker våpen, ammunisjon, komponenter og materiell med strategisk og dødelig kapabilitet. B-materiell dekker materiell av ikke-dødelig kapabilitet. Det er høyere terskel for å innvilge lisens for A-materiell enn for B-materiell, og høyere terskel for lisensinnvilgning for B-materiell enn for flerbruksvarer (Redd Barna \& Changemaker, 2020, s. 24). Norsk praksis er at grupper av land (landgruppe 1-4) samlet klareres som mottakere av materiellgrupper. Landgruppe 1 består av NATO-land, de nordiske landene og andre nærstående land, og er politisk forhåndsklarert for A- og B-materiell. Dette betyr ikke at alle lisenssøknader godkjennes, men at beslutningene tas administrativt av saksbehandlere i eksportkontrollseksjonen (Utenriksdepartementet, 2021, s. 2). Landgruppe 2 består av land som kan motta B-materiell, samt A-materiell ved regjeringsbehandling. Det er altså regjeringen ved utenriksministeren som godkjenner salg av A-materiell til land i landgruppe 2, som inkluderer Emiratene. Landgruppe 3, hvor Saudi-Arabia inngår, består av land som kun kan motta B-materiell. Landgruppe 4 kan ikke importere verken A- eller B-materiell fra Norge.

Den Saudi-ledede koalisjonen inkluderer noen av verdens største våpenimportører. I perioden 2016-2020 var fire av landene i koalisjonen på topp 10-listen over verdens våpenimportører; Saudi-Arabia lå øverst, etterfulgt av Egypt på tredjeplass, Qatar på åttendeplass og Emiratene på niendeplass (SIPRI, 2021). Flere av disse

\footnotetext{
${ }^{6}$ Forskrift av 19. juni 2013 gir regler om den operative gjennomføringen av kontrollen.

${ }^{7}$ Flerbruksvarer har både sivile og militære anvendelsesområder.

${ }^{8}$ Seksjonen forbereder også de årlige stortingsmeldingene om norsk eksportkontroll.
} 
landene, som alle mangler store nasjonale forsvarsindustrier, har markant økt sin våpenimport siden krigen $\mathrm{i}$ Jemen startet. Med dette er verdens samlede mest lovende markeder de siste årene nettopp landene som kriger i Jemen. Dette stiller vestlige eksportører, inkludert Norge, overfor et dilemma; krigen i Jemen trenger en løsning, men er samtidig et lukrativt mulighetsvindu for både kortsiktig og langsiktig profitt.

Norge har benyttet seg av mulighetsvinduet. Tabell 1 viser verdien av norsk eksport av militærmateriell til koalisjonslandene fra 2015 (året intervensjonen startet) og ut 2020 (siste år med tilgjengelig eksportdata). Tallene er selvrapporterte tall fra stortingsmeldingene om eksport av forsvarsmateriell fra Norge, og er som i stortingsmeldingene angitt i 1000 norske kroner og må ganges med 1000. Eksporten til koalisjonslandene har i $2015-2020$ ligget mellom 2 og $8 \%$ av den totale norske våpeneksporten; normalen er 2-4\%, mens 2016 var et toppår med $8 \%$. Eksporten dominerer altså ikke den norske salgsstatistikken, og man kan vanskelig argumentere for at den norske forsvarsindustriens overlevelse avhenger av koalisjonslandene.

To land i koalisjonen i Jemen er i landgruppe 2, og har begge mottatt A-materiell fra Norge under krigen; Emiratene og Kuwait. Emiratene har hatt en særlig aktiv rolle i krigen $i$ Jemen, og er det landet i koalisjonen som har mottatt mest A-materiell fra Norge. Derfor er det eksporten av A-materiell til Emiratene som har vært viet størst plass i debatten om den norske eksporten. Tabell 1 viser at det fra 2015 til 2016 var en mangedobling i eksporten til Emiratene; A-materielleksporten alene var 23,5 millioner i 2015, og økte til hele 100,5 millioner i 2016. Også 2017 var et stort år for eksport av A-materiell til Emiratene, med eksport til nesten 63 millioner. Til sammenligning var den samlede A- og B-materielleksporten til Emiratene ca. 18 millioner i 2013 og 44,5 millioner i 2014 (Meld. St. 5 (2017-2018), s. 31). Saudi-Arabia og Jordan er i landgruppe 3 og kan kun importere B-materiell og flerbruksmateriell fra Norge. I 2018 mottok Saudi-Arabia mer norsk B-materiell enn noen tidligere år.

Eksporten til koalisjonslandene var kontroversiell fra intervensjonens start. ${ }^{9}$ Sosialistisk Venstreparti (SV) fremmet i oktober 2017 forslag i Stortinget om stans i all eksport av militærmateriell til samtlige land i koalisjonen, men forslaget ble nedstemt (Innst. 104 S (2017-2018)). To ganger under krigen, i januar 2016 og desember 2017, har regjeringen imidlertid stanset eksport av A-materiell til Emiratene. Første gang, i januar 2016, ble en utførsel av ammunisjon fra Nammo til Emiratene suspendert. Suspensjonen illustrerte ifølge regjeringen en streng «føre var»-linje, begrunnet med fare for at ammunisjonen kunne anvendes i humanitærrettsbrudd i Jemen (Utenriksdepartementet, 2016). Her refererte man til ordlyden i eksportretningslinjene. Til tross for suspensionen, som varte til februar 2017, hadde eksport av A-materiell til Emiratene et rekordår i 2016. Mens regjeringen stadig gjentok at stansen i ammunisjonsutførsel til Emiratene var bevis på en «øre var»-linje, ble det faktum at eksport

\footnotetext{
${ }^{9}$ I en undersøkelse gjennomført avTNS Gallup i 2016 svarte for eksempel 92 \% nei på spørsmålet «Bør Norge selge militært utstyr og våpensystemer til land som begår krigsforbrytelser?».
} 


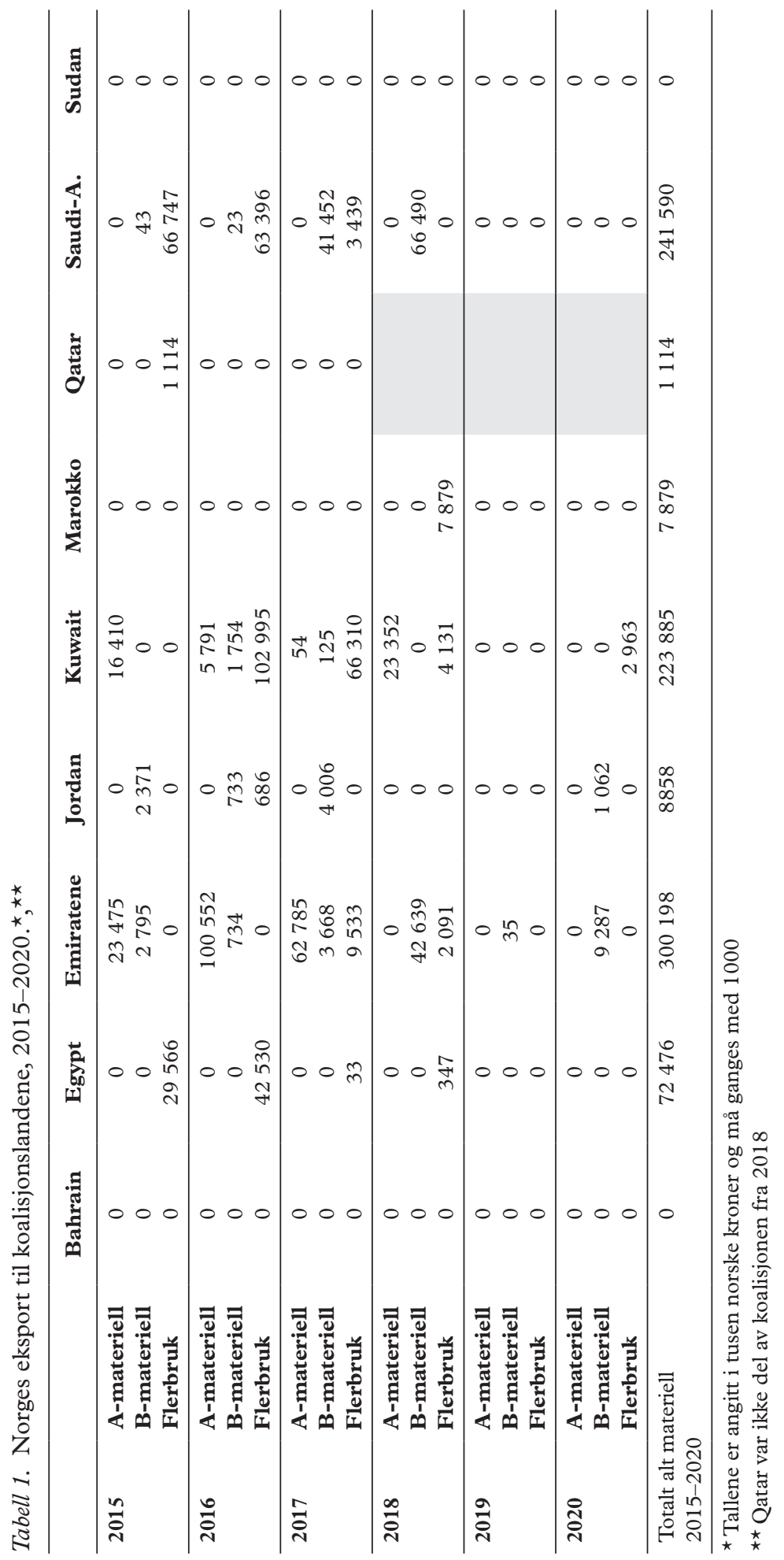


av øvrig A-materiell vedvarte underkommunisert. Resultatet var uklarhet rundt hva og hvor mye som var suspendert.

Suspensjonen av ammunisjon til Emiratene var midlertidig, og eksporten ble gjenopptatt i februar 2017. Gjenopptakelsen gikk under offentlighetens og Stortingets radar frem til august 2017, og det fremstod nærmest som om Utenriksdepartementet hadde smuglet ut endringen. Da gjenopptakelsen ble kjent, ble den umiddelbart gjenstand for betydelig omtale i media og debatt i Stortinget. Mange norske aviser tok utover høsten 2017 til orde for at eksporten var umoralsk, og et søk i Atekst Retriever viser bruk av terminologi som «djevelens advokat», "skammelig våpensalg» og "krigsprofitøren Norge» i beskrivelsene av eksporten. I Stortinget krevde SV en garanti fra regjeringen om at norsk ammunisjon solgt til Emiratene ikke ville brukes i Jemen (Stortinget, 2017a, s. 1421). En slik garanti ville ikke daværende utenriksminister Børge Brende gi (Stortinget, 2017b). Først 19. desember 2017, ti måneder etter gjenopptakelsen, kom en ny stans i eksporten til Emiratene, den andre i rekken. Denne gangen suspenderte regjeringen ved ny utenriksminister Ine Eriksen Søreide ikke bare én ammunisjonsutførsel, men all A-materielleksport til Emiratene. Årsaken var "den økende risikoen knyttet til [Emiratenes] militære engasjement i Jemen» og «stor bekymring for den humanitære situasjonen» i Jemen (Utenriksdepartementet, 2018a), som Søreide (2021a, s. 2) betegnet som «meget alvorlig». Drapet på tidligere president Saleh 4. desember 2017 hadde medført «en eskalering av situasjonen, noe som også gjorde risikobildet annerledes» (Søreide, 2018a, s. 2463). Beslutningen, tatt av den nye utenriksministeren selv (Søreide, 2021b), ble sagt å være en "helhetlig vurdering» basert på en streng "føre var»-linje (Søreide, 2018b). Suspensjonen, som Stortinget mente kom for sent (Innst. 105 S (2017-2018), s. 5), gjelder fortsatt, og vises i tabell 1 ved at det ikke har vært eksportert A-materiell til Emiratene etter 2017. Til tross for suspensjonen til Emiratene, mottok Kuwait norsk A-materiell i 2018.

Der A-materiell har blitt gjenstand for restriksjoner, var eksporten av B-materiell og militært flerbruksmateriell til flere av koalisjonslandene, deriblant både Emiratene og Saudi-Arabia, uberørt av suspensjonene. Det var altså aldri snakk om en full stans i eksport av militært materiell i desember 2017, men en delvis stans, hvor man prioriterte det mest kontroversielle og dødeligste utstyret. Riktignok annonserte regjeringen i desember 2017 en heving av terskelen for eksport av B-materiell til koalisjonslandene. Fra regjeringshold heter det seg at terskelen for å avslå eksport av B-materiell «er meget lav» og at «Utenriksdepartementets praksis er streng» (Utenriksdepartementet, 2021a). Likevel viser tabell 1 at det siden 2017 er solgt store mengder B-materiell og flerbruksvarer til land i koalisjonen. I 2018 eksporterte Norge mer B-materiell enn noen kalenderår tidligere til Emiratene. Kontroversene rundt eksporten av B-materiell til Emiratene fortsatte utover våren 2021, særlig etter at Riksrevisjonen i februar leverte en knusende rapport om håndhevingen av retningslinjene for eksportkontrollen. 13. april kastet Dagsrevyen lys over eksporten, etter at tall fra Statistisk sentralbyrå viste at Norge i 2020 hadde eksportert blant annet våpenkomponenter, diskutabelt nok kategorisert som B-materiell, til Emiratene. 
Eksporten av B-materiell til Saudi-Arabia har økt jevnlig i løpet av krigen i Jemen, med et toppår i 2018. Først i november 2018 besluttet regjeringen at det ikke skulle utstedes nye lisenser for eksport av B-materiell og militært flerbruksmateriell til Saudi-Arabia. Beslutningen kom i kjølvannet av likvideringen avWashington Postjournalisten Jamal Khashoggi ved det saudiske konsulatet i Istanbul. Likvideringen medførte at flere land - inkludert Danmark, Finland, Tyskland og Nederland suspenderte lisenser til Saudi-Arabia. Det ville udiskutabelt tatt seg dårlig ut om Norge ikke fulgte etter. Eksporten av B- og flerbruksmateriell til andre koalisjonsland fikk imidlertid fortsette, hvilket indikerer at det ikke var den stadig forverrede situasjonen $\mathrm{i}$ Jemen - men Saudi-Arabias håndtering av regimekritikere - som var utslagsgivende for stansen i eksport til Saudi-Arabia.

Oppsummert har vi sett at tross noen få restriksjoner begrunnet med en «føre var-linje», preges eksporten til koalisjonslandene av kontinuitet samt betydelig treghet $\mathrm{i}$ beslutninger om suspensjoner.

\section{Legitimeringsgrunnlaget for eksport til koalisjonen i Jemen}

I det følgende presenteres og diskuteres fem sentrale dimensjoner i norske myndigheters legitimering av eksporten til koalisjonslandene i perioden 2015-2021. Fire tar form som offentlig kommuniserte forsikringer om at norske myndigheter har kontroll og følger regelverket. En femte dimensjon, som søkes ikke-kommunisert overfor offentligheten, omhandler hensyn til forsvarsindustrien og industriens markedsmuligheter. Samlet utgjør dimensjonene legitimeringsgrunnlaget for eksporten.

\section{Dimensjon I: Ett av verdens strengeste regelverk}

En replikk som stadig har vært gjentatt når kritiske spørsmål om norsk våpeneksport til koalisjonslandene har blitt rettet mot regjering og embetsverk under krigen i Jemen, er frasen «Norge har ett av verdens strengeste regelverk for eksport av forsvarsmateriell» (Meld. St. 19 (2017-2018), s. 7; Utenriksdepartementet, 2018b, 2021b, s. 1). I januar 2016 kritiserte daværende statssekretær i Utenriksdepartementet, Tore Hattrem, Dagbladets kritiske dekning av Norges våpeneksport til Jemen som «tendensiøs», og parerte med motargumenter om at Norge "har et meget strengt lovverk og retningslinjer for eksport av våpen, ammunisjon og annet militært utstyr. Et av de strengeste i verden» (Hattrem, 2016). At Norges regelverk er «strengt» og "ett av verdens strengeste» har etter hvert blitt for rutinemessig repeterte standardfraser å regne når regjeringens eksportlinje kritiseres.

Påpekningen av regelverkets kvalitet fremstår som en forsikring om at ikke bare er gode retningslinjer etablert, men politikken er også i tråd med dem. Dette viser at man i Norge har noe av den samme dynamikken som i Storbritannia, som i møte med kritikken mot forsendelsene til Saudi-Arabia har forsvart eksporten ved å påberope seg ett av verdens strengeste regelverk (Stavrianakis, 2017). Logikken, både i Storbritannia og i Norge, virker å være at ved å påpeke at man har et bra regelverk og 
gode rutiner for å følge det, kan man ikke ha brutt det. Det ligger dessuten implisitt i påstanden at noen andre har et dårligere regelverk.

Utfallet av bruken av denne forsikringen er en interessant forestilling. La oss tenke oss at utenriksministeren stilles følgende spørsmål: «Hvorfor fortsetter norske myndigheter å eksportere B-materiell til Emiratene?» Spørsmålet er konkret; spørsmålsstiller ønsker innsikt i motivasjonen bak eksporten. Den norske strategien er imidlertid å besvare denne typen spørsmål med standardsvaret «Norge har ett av verdens strengeste regelverk for eksport av forsvarsmateriell» (Meld. St. 19 (2017-2018), s. 7). Altså besvares ikke det stilte spørsmålet, men spørsmålet "har Norge et bra regelverk?». Svaret som gis er således et unnlatelsessvar, og signaliserer at debatt ikke trengs når regelverket er strengt.

Ufeilbarligheten til det norske regelverket kan imidlertid diskuteres. For det første er eksportkontrollregelverk basert på risikovurdering alltid åpne for fortolkning, hvilket potensielt svekker implementering. Skillet mellom A-, B- og flerbruksmateriell er dessuten ikke uproblematisk, ettersom bruk av A-materiell ofte forutsetter B-materiell. For eksempel er kommunikasjonsutstyr B-materiell, men essensielt i bombetokter fra luften for kommunikasjon mellom pilotene. Norge har siden 2015 solgt mye kommunikasjonsutstyr til Saudi-Arabia. Det er tidvis også uklart om materiell skal klassifiseres som A- eller B-materiell, og mobilitet mellom kategoriene forekommer. Dessuten er det praktiseringen av regelverket, ikke dets eksistens, som til syvende og sist har betydning.

\section{Dimensjon 2: Norsk materiell ikke brukt i Jemen}

Helt siden kontroversene rundt Norges salg av forsvarsmateriell til koalisjonslandene startet, har norske myndigheter gjentatt det som har blitt nok en standardfrase, nemlig at det ikke finnes bevis for bruk av norsk materiell i Jemen. Daværende statssekretær Tore Hattrem var tidlig i 2016 nådeløs i respons til kritikken mot regjeringen: «Påstander om at norske våpen brukes i krigen i Jemen er direkte feil. [...] Det foreligger heller ingen informasjon om at militært utstyr levert fra Norge til Saudi-Arabia, er brukt i krigføringen i Jemen» (Eisenträger \& Foss, 2016). Man har i ettertid moderert ordlyden; i stedet for å omtale påstander som "direkte feil", snakker man nå om at man «ikke har informasjon om» eller «ikke er kjent med». Flere suksessive stortingsmeldinger gjentar variasjoner av standardfrasen: i Meld. St. 19 (2017-2018, s. 17) heter det at «Utenriksdepartementet er ikke kjent med at norsk forsvarsmateriell er brukt i krigen i Jemen", og i Meld. St. 26 (2018-2019, s. 38) heter det at det «foreligger ikke informasjon om at forsvarsmateriell fra Norge er avledet til Jemen». Senest i mai 2021 formidlet utenriksminister Søreide at man med negativt resultat hadde lett med lys og lykte etter bruk av norsk materiell i Jemen:

Det foreligger ikke informasjon om at norsk forsvarsmateriell er kommet på avveie og blitt brukt i Jemen. [...] I 2018 ble det fremsatt slike påstander. Vi gjorde derfor grundige undersøkelser. Hverken gjennom samtaler med vedkommende som kom 
med påstanden, eller gjennom undersøkelser via våre ambassader, delegasjoner og internasjonale nettverk kunne påstanden verifiseres. Heller ikke andre kilder kunne gi informasjon som underbygget påstanden. (Søreide, 2021b)

Også denne legitimeringen tar form som en forsikring; om at norske våpen ikke er involvert i Jemen, og at alt dermed er under kontroll. Logikken er at så lenge det ikke er bevis for det motsatte, har ikke bruk av norsk materiell forekommet, og da trenger man heller ikke stanse eksporten. Øyner man igjen til britenes legitimeringsstrategi, har ikke britene benektet bruk av britisk materiell i Jemen; til det har bruken vært for åpenbar. Til giengjeld har britiske myndigheter lenge benektet at Saudi-Arabia har brutt humanitærretten i Jemen (Stavrianakis, 2017), et resonnement med konsekvens at britiske våpen ikke kan ha blitt brukt $\mathrm{i}$ humanitærrettsbrudd $\mathrm{i}$ Jemen. Således foreligger paralleller mellom strategiene.

Retningslinjene nedfelt i ATT og EUs felles posisjon skal imidlertid praktiseres på basis av en evaluering av fremtidig risiko, ikke på basis av bevis på bruk av et spesifikt lands materiell (Lustgarten, 2020, s. 76). En risikovurdering i tråd med EUs kriterier skal ifølge brukermanualen til EUs felles posisjon (Rådet for Den europeiske union, 2019) besvare spørsmål om importørenes handlinger i nyere tid: Har importørene tidligere begått humanitærrettsbrudd i Jemen? Har lignende materiell vært brukt av koalisjonen i humanitærrettsbrudd i Jemen? Har importøren tidligere forsynt opprørsgrupper med våpen? Manglende bevis for bruk av norsk materiell medfører ikke fravær av risiko i svarene på disse spørsmålene. Flere faktorer indikerer dessuten risiko for bruk av norsk materiell i humanitærrettsbrudd i Jemen. Man vet for eksempel at våpen fra en rekke NATO-land som Norge eksporterer både ferdige våpen og komponenter til, har blitt brukt $\mathrm{i}$ humanitærrettsbrudd $\mathrm{i}$ Jemen (Brian, 2021). Det er også kjent at flere av våpnene som allerede er dokumentert anvendt av koalisjonen i Jemen kan bruke ammunisjon fra Norge (Changemaker \& Redd Barna, 2021).

Norske myndigheter har dessuten eksportert til Emiratene til tross for å samtidig ha anerkjent risikoen for at norsk materiell kan anvendes i Jemen. Riksrevisjonens rapport antydet i februar 2021 at mens man utad betonte manglende bevis for bruk av norsk materiell i Jemen, anerkjente man internt i Utenriksdepartementet risikoen for at norsk materiell eksportert til Emiratene kunne anvendes i Jemen (Riksrevisjonen, 2021, s. 17). Detaljene i denne informasjonen befant seg imidlertid i revisjonsrapportens hemmeligholdte vedlegg, og var ukjent for offentligheten før de i mai 2021 ble gjengitt i flere saker i Aftenposten. Aftenpostens giengivelser viser at Utenriksdepartementet, i behandlingen av en lisenssøknad om eksport av ammunisjon til Emiratene, uttrykte «usikkerhet knyttet til hvor ammunisjonen kan havne», og at det var "meget sannsynlig» at Emiratenes styrker i Jemen brukte den samme typen ammunisjon som de søkte å importere fra Norge (Gjerde \& Lom, 2021). Konklusjonen om at det er «meget sannsynlig» at Emiratenes styrker brukte denne typen ammunisjon i Jemen, skal under ATT og EUs felles posisjon medføre 
lisensavslag. Lisenssøknaden ble likevel innvilget. Ved å i realiteten fremlegge et krav om bevis, snarere enn å vektlegge risikofaktorer, legger norske myndigheter beviskravet svært høyt. Med mindre man har fotobevis for at norsk materiell er anvendt i Jemen - noe som er et høyt krav fra et konfliktområde - kan man ikke tilfredsstille beviskravet. Venter man på bevis, legger man seg videre på en reaktiv tilnærming, snarere enn den preventive, risikobaserte tilnærmingen ATT og EUs felles posisjon omfavner.

\section{Dimensjon 3: Intervensjonen er lovlig}

En ytterligere dimensjon i legitimeringen er argumentet om at eksporten er innenfor retningslinjene fordi intervensjonen i Jemen er lovlig under FN-pakten; koalisjonen «intervenerer militært etter samtykke fra den lovlige regjeringen i landet det interveneres i» (Utenriksdepartementet, 2021b, s. 5). ${ }^{10}$ Denne dimensjonen er enda en forsikring; her om at man opererer innenfor regelverket fordi intervensjonen i seg selv er lovlig. Også denne dimensjonen er sporbar annetsteds; da rettssaken mot britiske eksportmyndigheter startet, argumenterte myndighetene for at eksporten til Saudi-Arabia var basert på en "sound legal basis for the intervention" (Secretary of State for Business, Innovation and Skills, 2016, s. 6).

Satt opp mot lov og retningslinjer, oppstår imidlertid to problemer når man fra norsk side legger argumentet om lovlig intervensjon til grunn for eksporten. For det første er regjeringens resonnement ikke i tråd med internasjonale våpeneksportkontrollregimer. Verken ATT eller EUs felles posisjon betoner intervensjonens lovlighet (jus ad bellum), men omtaler brudd på internasjonal humanitær rett generelt (jus in bello), uavhengig av om en intervensjon er lovlig eller ikke (NIM, 2018, s. 6-7). Som Norges nasjonale institusjon for menneskerettigheter påminner $\mathrm{i}$ et innspill til myndighetene: "Hele poenget med internasjonal humanitær rett er at den skal gjelde i alle kriger og konflikter uansett hvem som har 'rett'» (NIM, 2018, s. 5). Spørsmålet om intervensjonens lovlighet er således ikke juridisk relevant, og skal ikke substituere risikovurderingens betoning av jus in bello.

For det andre er argumentet om legitim intervensjon i konflikt med det som omtales som bærebjelken i den norske våpeneksportkontrollen, nemlig Stortingets 1959-vedtak. 1959-vedtaket stadfester at «hovedsynspunktet bør være at Norge ikke vil tillate salg av våpen og ammunisjon til områder hvor det er krig eller krig truer, eller til land hvor det er borgerkrig» (Meld. St. 5 (2017-2018), s. 9). Solberg-regjeringen har imidlertid uttrykt at «[p] raksis har vært at stater som intervenerer etter samtykke fra et lands lovlige myndigheter, ikke anses omfattet

\footnotetext{
${ }^{10}$ Intervensjonens legitimitet stammer også fra FNs sikkerhetsråds resolusjon 2216, som 15. april 2015 slo ned på houtienes krigføring og stadfestet president Hadis regjering som Jemens rettmessige myndighet.
} 
av 1959-vedtaket» (Meld. St. 19 (2017-2018), s. 16). Det er på basis av denne angivelige praksisen at regjeringen har konkludert med at 1959-vedtaket ikke begrenser eksporten til koalisjonslandene, ettersom koalisjonen intervenerte på presidentens forespørsel.

Den praktiseringen av 1959-vedtaket som regjeringen legger til grunn for eksporten - nemlig at eksport kan videreføres ved lovlig intervensjon - har imidlertid aldri vært ment å gjelde for land i Midtøsten. Foranledningen for praktiseringen Solberg-regjeringen viser til, var at 1959-vedtaket sent på 1960-tallet stod i veien for eksporten til USA da USA kriget i Vietnam. USA var en viktig alliert og sikkerhetsgarantist, og hadde vært sentral i den norske forsvarsindustriens utvikling under Våpenhjelpprogrammet. Selv om USA kriget iVietnam, og deler av det Norge skulle eksportere til USA var gammelt materiell som nå skulle til Vietnam, fant man det politisk vanskelig å nekte forsendelser til USA. Stortinget vedtok i 1967 derfor en innstilling som skilte mellom kommersiell og sikkerhetspolitisk motivert eksport (Innst. 35 S (1967-1968)). 1959-vedtaket skulle gjelde for kommersiell eksport, men ikke for sikkerhetspolitisk motivert eksport, derunder eksporten til USA (Wicken, 1992, s. 51-52). Med sikkerhetspolitisk motivert eksport mente Stortinget «[våpeneksport] i forbindelse med planer trukket opp i NATOs forsvarsorganisasjon og som er godtatt av Norge eller basert på våpenhjelpsavtale mellom Norge og noen av NATOs andre medlemsland" (Innst. 35 S (1967-1968), s. 50). Man fikk altså en liberalisering av 1959-vedtaket, ved at eksport til stater i krig i noen tilfeller var greit, men liberaliseringen i 1967 var forbeholdt sikkerhetspolitisk motivert eksport, fortrinnsvis alliansehensyn.

Koalisjonslandene representerer imidlertid en gruppe land hvor eksport fra Norge ikke kan anses som annet enn kommersielt og økonomisk motivert; de omtales som "fremvoksende markeder for norsk forsvarsindustri» (Meld. St. 36 (2015-2016), s. 12). Landene har ingen direkte funksjon i norsk sikkerhetspolitisk sammenheng, og historisk har hovedlinjen i norsk eksportpolitikk dessuten vært at Norge ikke skal eksportere våpen til land i Midtøsten. Da Norge startet sin våpeneksport til Emiratene i 2009, ble det av myndighetene omtalt som en liberalisering av norsk våpeneksport (Gjerde \& Lom, 2021).

Verken 1959-vedtaket eller 1967-liberaliseringen åpner altså for regjeringens praksis. Samtidig har det aldri blitt tydeliggiort når, hvordan og hvorfor den nye praksisen oppstod. Det er normalt at saker av viktig utenriks- og sikkerhetspolitisk betydning drøftes i Den utvidede utenriks- og forsvarskomité (DUUK) før beslutninger fattes. Liberaliseringen i 1967 ble drøftet i DUUK, og ble formalisert i Innst. 35 S (1967-1968). Til sammenligning har Stortinget aldri godkjent at 1959vedtaket skal åpne for kommersiell eksport til intervenerende land. Spørsmålet om eksporten til Emiratene har heller aldri stått på dagsorden i DUUK (Gjerde \& Lom, 2021). I offentlig tilgjengelig materiale fremgår denne fortolkningen og praktiseringen av 1959-vedtaket for første gang i Solberg-regjeringens stortingsmelding om eksportkontrollen i 2016, publisert i oktober 2018 (Meld. St. 5 (2017-2018), s. 9). 
Etter dette har beretningen om denne praktiseringen av 1959-vedtaket inngått som en sentral del av legitimeringsgrunnlaget for eksporten til land i koalisjonen. Eksportkontrollmeldingen for 2016 avdekte videre når praksisen hadde oppstått; det var krigen i Jemen som hadde "aktualisert en vurdering av begrepet 'land hvor det er borgerkrig'» (Meld. St. 5 (2017-2018), s. 9). Altså hadde det ved krigens start oppstått et behov for å vurdere hvorvidt 1959-vedtaket rammet eksporten til koalisjonslandene, og spørsmålet havnet på Solberg-regjeringens bord. I mai $2021 \mathrm{kom}$ det via Aftenpostens lekkasjer frem at det var Utenriksdepartementets rettsavdeling som i 2015 hadde konkludert med at våpeneksporten til Emiratene ikke var i strid med 1959-vedtaket. Rettsavdelingen skrev i 2015 at «[p]raksis har vært at intervenerende stater ikke anses som omfattet av 1959-vedtaket", og at "sentrale NATO-partnere som USA, UK og Frankrike har intervenert $\mathrm{i}$ andre land en rekke ganger, men det har ikke vært aktuelt å stanse et salg av våpen og ammunisjon til disse landene» (sitert i Gjerde \& Lom 2021). Når regjeringen henviser til praksis, er det altså snakk om en praksis som ikke er behandlet i Stortinget eller diskutert i DUUK, men i Utenriksdepartementets rettsavdeling. Denne politisk nokså store vurderingen var dessuten gjort i en kort, intern e-post i Utenriksdepartementet, hvorpå Riksrevisjonen (2021, s. 17) uttalte at saken ikke hadde vært grundig nok utredet til å være «en så prinsipielt viktig og politisk aktuell sak». Det vekket dessuten oppsikt at Utenriksdepartementet hadde sidestilt koalisjonslandene og NATO-land da de konkluderte med at eksporten kunne opprettholdes. Sidestillingen kan bare forstås dithen at man enten ikke har satt seg inn i betingelsene for at Norge i 1967 åpnet for å eksportere til intervenerende land, eller etablert en ny praksis uten å gå omveien via DUUK og Stortinget.

\section{Dimensjon 4: Eksport til nasjonalt forsvar}

Nok en sentral del av det norske legitimeringsgrunnlaget, og nok en forsikring, er at det forutsettes at eksporten skal dekke mottakerlandenes egne forsvarsbehov og ikke skal benyttes i Jemen. Begrunnelsen har spesielt vært mobilisert ved eksport av A-materiell til Emiratene. Den har imidlertid ikke vært å se gjennom alle årene av krigen, og er for første gang å spore i eksportmeldingen for kalenderåret 2018, presentert for Stortinget i juni 2019. Her heter det at det «forutsettes [...] at forsvarsmateriell fra Norge utelukkende er for mottakerlandets eget forsvar» (Meld. St. 26 (2018-2019), s. 17). Det faktum at den ikke opptrer i begrunnelsene før i 2019, indikerer at forutsetningen ble til i møte med den økende kritikken av eksporten til koalisjonslandene. En slik tolkning underbygges av Riksrevisjonens funn om at forutsetningen ikke alltid har vært til stede i de utstedte lisensene til Emiratene (Riksrevisjonen, 2021, s. 17). Siden 2019 har den imidlertid vært en sentral del av legitimeringsgrunnlaget. Søreide gjentok i 2021 forsikringen i sitt svar til Riksrevisjonens kritikk av Utenriksdepartementets lisensbehandling overfor Emiratene: «Konkret er det en forutsetning at utstyr som er anskaffet fra 
Norge er for [Emiratenes] egne forsvarsbehov, og ikke skal benyttes i Jemen eller til å begå brudd på den internasjonale humanitærretten» (Utenriksdepartementet, 2021b, s. 5).

Også denne delen av legitimeringsgrunnlaget støter imidlertid på utfordringer i praksis. Problemet her er at norske myndigheter ikke med sikkerhet kan konkludere med at norsk materiell ikke vil avledes til bruk i Jemen. Tre årsaker kan nevnes.

For det første: Sluttbrukererklæringer og reeksportklausuler, som kreves for A-materielleksport til landgruppe 2, spiller angivelig en sentral rolle i å sikre at forutsetningen om eksport kun til nasjonalt forsvar blir møtt. ${ }^{11}$ Man antar at sluttbrukererklæringer har avskrekkende virkning ved at lovnadsbrudd «vil innebære et betydelig svekket omdømme og få negative konsekvenser for [import]landets senere mulighet til å anskaffe materiell fra Norge eller andre leverandørland» (Utenriksdepartementet, 2021b, s. 6). Et betimelig spørsmål er om den avskrekkende virkningen er reell, og om importørene av norskproduserte våpen respekterer sluttbrukererklæringer. I Innst. 213 S (2015-2016, s. 20) argumenterte Stortingets kontroll- og konstitusjonskomité for at en sluttbrukererklæring i realiteten kan være en så forenklet egenerklæring at den «vitner om en uakseptabel manglende risikovurdering knyttet til dokumentasjonen som blir fremlagt», og at det ikke holder å stole på at eksportøren forelegger korrekte opplysninger. Vektleggingen av lovnader og sluttbrukererklæringers verdi står også i et visst misforhold til bevisbyrden rundt Emiratenes materiellforsendelser til Jemen. Amnesty International (2019) har dokumentert at Emiratene har overført både våpen og annet militært utstyr, kjøpt fra vestlige land, til væpnede militsgrupper i Jemen. Informasjonen om Emiratenes videreeksport til grupper i Jemen er endatil fanget opp og diskutert av norske myndigheter (se Meld. St. 26 (2018-2019), s. 38). Lekkede, klausulerte dokumenter viser også at norske myndigheter eksplisitt har anerkjent avledningsrisikoen ved eksport til Emiratene (Gjerde \& Lom 2021; Riksrevisjonen, 2021, s. 17).

For det andre har norske myndigheter ved flere anledninger unnlatt å formulere krav om at Emiratenes styrker ikke skal bringe med seg norsk materiell inn i Jemen, til tross for at Søreide har forsikret Stortinget om at innvilgelse av lisenser av A-materiell til Emiratene forutsetter fremlegging av sluttbrukererklæring med reeksportklausul (Stortinget, 2017c). Riksrevisjonen (2021, s. 17) fant at «flere

\footnotetext{
${ }^{11}$ En «sluttbrukererklæring» er en garanti gitt til eksportøren om at det oppgitte mottakerlandet er den endelige bruker av materiellet. Slike erklæringer fastslår hvem sluttbruker er og importens formål. Sluttbrukererklæringen inneholder i noen tilfeller en "reeksporterklæring», hvor importøren gir en formell forsikring om at materiellet ikke skal eksporteres videre uten opprinnelig eksportørs samtykke. Sluttbrukererklæringer med reeksportklausul innebærer således at sluttbruker forplikter seg til å be om godkjenning fra norske myndigheter før materiellet videresendes innenlands eller reeksporteres.
} 
lisenser [...] som gjelder Emiratenes militære styrker, ikke har eksplisitte forutsetninger om at utstyret ikke skal brukes utenfor Emiratene, verken i lisensvilkårene eller i sluttbrukererklæringene». I praksis betyr dette at flere lisenser for eksport til Emiratene er gitt uten lovnadene utenriksministeren har forsikret om at foreligger, og at kontrollen med norsk materiell er dårligere enn man kommuniserer at den er. Dette har medført påstand om at utenriksministeren har villedet Stortinget (Hoel, 2021).

For det tredje er krav til sluttbruker- og reeksporterklæringer lave ved eksport til landgruppe 1 på en måte som i praksis svekker evnen til å kontrollere at norsk materiell ikke kommer til Jemen via andre land. Våpeneksporten til disse landene «baserer seg på en grunnleggende tillit som innebærer at våpen som er anskaffet ikke blir reeksportert uten at det opprinnelige eksportlandet blir konsultert» (Meld. St. 19 (2017-2018), s. 15). Samtidig utgjør land i landgruppe 1, særlig USA og Storbritannia, de største eksportørene til koalisjonslandene. Norge er dessuten en stor delleverandør til alliertes våpensystemer, og dokumentasjon om sluttbruk foreligger ikke dersom det ferdige produktet ikke fremstår som norsk (Meld. St. 19 (2017-2018), s. 9).

\section{Dimensjon 5: Industri- og markedshensyn}

Artikkelens teoridel viste hvordan materielle argumenter kan inngå i staters legitimering av våpeneksporten, i Norge særlig i eksporten til allierte. Ingen av de fire dimensjonene ved legitimeringsgrunnlaget diskutert over betoner materielle motiver; snarere er de forsikringer om at norske myndigheter tar de hensyn som skal tas. Regjeringen har, som forventet, heller aldri eksplisitt uttalt at det ligger materielle motiver til grunn for eksporten til koalisjonslandene. Likevel vet man at det ligger materielle motiver bak eksporten til landene som kriger i Jemen.

Regjeringen har for det første implisitt informert om materielle motiver ved gjentagende uttrykk for viktigheten av satsningen på denne landgruppen. Koalisjonslandene ble $\mathrm{i}$ stortingsmeldingene om eksportkontrollen lenge omtalt som "fremvoksende markeder for norsk forsvarsindustri» (Meld. St. 36 (2015-2016), s. 12; Meld. St. 5 (2017-2018), s. 16; Meld. St. 19 (2017-2018), s. 16-17). At Nammo i 2015 etablerte et salgskontor i Emiratene er et klart uttrykk for markedssatsning. Ordlyden har riktignok endret seg etter hvert som krigen i Jemen har eskalert; i stortingsmeldingene om eksportkontrollen for kalenderårene 2018, 2019 og 2020 omtales ikke lenger koalisjonslandene som «fremvoksende markeder». I en stortingsdebatt i januar 2019, hvor utenriksminister Søreide skulle besvare spørsmål om våpeneksporten til land i koalisjonen, valgte utenriksministeren likevel å åpne med å gi uttrykk for forsvarsindustriens materielle viktighet for Norge: «Den er viktig for vår beredskap, den er viktig for utvikling av høyteknologi, den gir betydelige arbeidsplasser, og ikke minst har den også stor overføringsverdi til sivil sektor, som er viktig for norsk innovasjon» (Søreide, 2019, s. 2043). Betoningen av militær beredskap, teknologiutvikling og arbeidsplasser selv i en debatt om våpeneksporten til landene 


\section{Susanne Therese Hansen}

involvert i krigen i Jemen fremstod som en retorisk påminner til kritikere om industriens viktighet.

For det andre fikk man i mai 2021, gjennom Aftenpostens lekkasje av vedlegget fra Riksrevisjonens rapport, svart på hvitt se at industri- og markedshensyn hadde vært en del av vurderingsgrunnlaget. Aftenposten gjenga interne notater som viste hvordan Utenriksdepartementet, i en behandling av eksportlisenser til Emiratene, ga uttrykk for at avslag på lisenssøknader angivelig vil skape «store utfordringer» for eksportørene, og vil kunne ødelegge Emiratene som marked for norske forsvarsbedrifter i fremtiden (Gjerde \& Lom 2021). Å ta industrihensyn i situasjoner med tydelig risiko for at materiellet kan brukes i humanitærrettsbrudd, strider imot intensjonen i de internasjonale avtalene Norge er bundet av. Industri- og markedshensyn anses som legitime, men skal ikke påvirke ivaretakelsen av eksportkontrollkriteriene. Artikkel 10 i EUs felles posisjon sier for eksempel at land kan hensynta "economic, social, commercial and industrial interests, [but] these factors shall not affect the application of the [export] criteria» (Rådet for Den europeiske union, 2008, s. 103).

Selv om den lekkede informasjonen viser at konsekvenser for industrien ble vurdert, er det høyst uvisst hvor utslagsgivende slike hensyn har vært for beslutningene om vedvarende eksport. Vel så sentralt for denne artikkelens formål som det faktum at industri- og markedshensyn ble vurdert, er imidlertid regjeringens utelatelse av industri- og markedshensyn fra fortellingen om Norges våpeneksport til land som kriger i Jemen, manifestert gjennom hemmelighold av vedlegget fra Riksrevisjonens rapport. Norske myndigheter insisterer fortsatt, selv etter lekkasjene, på at det lekkede vedlegget skal forbli gradert etter sikkerhetsloven. Riksrevisjonen selv mener dokumentet ikke inneholder noe som kan skade rikets sikkerhet (Riksrevisjonen, 2020). Utelatelse og ikke-kommunikasjon gjennom hemmelighold kan i seg selv leses som en legitimeringshandling, for eksempel ved at det som ikke kommuniseres antas å kunne forringe politikkens legitimitet og derfor holdes skjult. Dette kan deretter indirekte bidra til å underbygge de øvrige legitimeringsstrategienes troverdighet.

Norske myndigheter har antageligvis gått lenger enn en del andre lands myndigheter i å tildekke materielle motiver bak eksporten. Selv om det har vært lite eksplisitt betoning av materielle motiver blant europeiske land, har åpenbare materielle hensyn vært å spore i flere beslutninger. Eksportkontrollmyndighetene i Vallonia ${ }^{12}$ nektet for eksempel i 2018 å suspendere våpeneksport til Saudi-Arabia så lenge ikke alle EU-land ble enige om å gjøre det samme (Ligues des Droits Humains, 2018). Dette synliggjorde ett av de store dilemmaene i våpeneksportkontrollen; mange vegrer seg for å avslå markedsmuligheter som konkurrenter vil plukke opp.

${ }^{12}$ I Belgia er eksportkontroll et regionalt ansvar, fordelt på de regionale myndighetene i Vallonia, Flandern og Brussel. 
Tabell 2 under oppsummerer de fem dimensjonene i legitimeringsgrunnlaget og deres forhold til regelverket.

Tabell 2. Legitimeringsgrunnlaget

\begin{tabular}{lll}
\hline $\begin{array}{l}\text { Dimensjoner ved } \\
\text { legitimeringen }\end{array}$ & Detaljer & Forhold til regelverk \\
\hline $\begin{array}{l}\text { 1. Ett av verdens } \\
\text { strengeste regelverk }\end{array}$ & $\begin{array}{l}\text { Offentlig kommunisert forsikring om } \\
\text { at regelverket er bra og prosedyrer } \\
\text { følges }\end{array}$ & $\begin{array}{l}\text { Praktisering av regelverket, ikke dets } \\
\text { eksistens, avgjør dets styrke. }\end{array}$ \\
\hline $\begin{array}{l}\text { 2. Norsk materiell ikke } \\
\text { brukt i Jemen }\end{array}$ & $\begin{array}{l}\text { Offentlig kommunisert forsikring om } \\
\text { at det ikke foreligger bevis på at norsk } \\
\text { materiell er brukt i Jemen }\end{array}$ & $\begin{array}{l}\text { Regelverket skal praktiseres på basis } \\
\text { av evaluering av risiko, ikke på basis av } \\
\text { bevis for bruk av enkeltlands materiell. }\end{array}$ \\
\hline $\begin{array}{l}\text { 3. Intervensjonen er } \\
\text { lovlig }\end{array}$ & $\begin{array}{l}\text { Offentlig kommunisert forsikring } \\
\text { om at eksporten er forsvarlig fordi } \\
\text { koalisjonen intervenerer på lovlig } \\
\text { grunnlag }\end{array}$ & $\begin{array}{l}\text { Intervensjonens lovlighet er } \\
\text { irrelevant under ATT og EUs felles } \\
\text { posisjon. Praksisen bryter også med } \\
\text { 1959-vedtaket og 1967-liberaliseringen. }\end{array}$ \\
\hline $\begin{array}{l}\text { 4. Eksport til nasjonalt } \\
\text { forsvar }\end{array}$ & $\begin{array}{l}\text { Offentlig kommunisert forsikring } \\
\text { om at eksporten skal dekke } \\
\text { mottakerlandets egne forsvarsbehov } \\
\text { og ikke benyttes i Jemen }\end{array}$ & $\begin{array}{l}\text { Sluttbrukererklæringer skal sikre at } \\
\text { premisset om eksport til nasjonalt } \\
\text { forsvar overholdes, men er ikke alltid } \\
\text { respektert av importøren, eller alltid til } \\
\text { stede fra norsk side. }\end{array}$ \\
\hline $\begin{array}{l}\text { 5. Industri- og } \\
\text { markedshensyn }\end{array}$ & $\begin{array}{l}\text { En ikke offentlig kommunisert } \\
\text { bekymring om at suspensjoner kan } \\
\text { skade industri- og markedsmuligheter }\end{array}$ & $\begin{array}{l}\text { Industri- og markedshensyn er anerkjent } \\
\text { som legitime motiver for våpeneksport, } \\
\text { men skal ikke påvirke risikovurderingen } \\
\text { og regelverksanvendelsen. }\end{array}$ \\
\hline
\end{tabular}

\section{Konklusjon}

Denne artikkelen satte seg som mål å forklare hvordan norske myndigheter, i møte med økende kritikk, har legitimert våpeneksporten til land som kriger $\mathrm{i}$ Jemen. Artikkelen har vist at legitimeringen er konstruert rundt fem dimensjoner. Fire dimensjoner tar form som offentlig kommuniserte forsikringer; om at regelverket er bra, om at det ikke foreligger bevis for bruk av norskprodusert materiell i Jemen, om at eksporten er innenfor retningslinjene fordi intervensjonen er lovlig, og om at importørene har gitt lovnader om å ikke anvende våpnene i Jemen. En femte dimensjon tar form som ikke-kommunikasjon av at materielle industri- og markedshensyn har inngått i beslutningsgrunnlaget. En legitimeringsstrategi bygd opp rundt kombinasjonen av forsikringer og utelatelse gir viktig informasjon om hvordan ansvarlige myndigheter forsøker å navigere i denne sensitive saken i norsk eksporthistorie. Forsikringer og utelatelse fremstår som virkemidler for å signalisere at norske myndigheter har kontroll, berolige meningsmotstandere og redusere kritikk. Det er dermed vanskelig å komme unna artikkelens første konklusjon: Kombinasjonen av forsikringer og utelatelse viser at legitimeringen av eksporten til koalisjonslandene i stor grad er ment å berolige kritikere.

Vi vet at materielle motiver kan spille en rolle i staters legitimering av våpeneksporten. I Norge gjelder dette særlig ved eksport til allierte. Vi forventet imidlertid 


\section{Susanne Therese Hansen}

å finne at jo mer kontroversiell eksporten er, jo mer vil myndighetene giøre for å overbevise om at eksporten skjer i henhold til retningslinjene, og jo mindre betont vil materielle interesser trolig bli. Norske myndigheters legitimering av våpeneksporten til koalisjonslandene bekrefter i stor grad disse forventningene. Myndighetene har lagt vekt på å forsikre om at man har kontroll og at Norge følger lovverket. Legitimeringen gir som forventet også sparsommelig informasjon om materielle motiver bak eksporten; denne informasjonen kom først gjennom medias lekkasjer av gradert informasjon.

Hva sier legitimeringen om regelverksanvendelsen? Man kommer ikke unna det faktum at regjeringens eksportlinje bryter med intensjonen i 1959-vedtaket og 1967-liberaliseringen. Det Erna Solbergs regjering har vist til som «norsk praksis», er i høyeste grad nyoppstått norsk praksis. Hva angår Norges internasjonale forpliktelser, er risikovurdering selve metodikken i juridisk bindende internasjonale avtaler for våpeneksporten. Metodikken krever praktisering av en føre-var-linje, blant annet gjennom en nøye risikovurdering av importørens handlinger i fortid og samtid. Problemet for norske myndigheter er at alle begrunnelsene som legges til grunn for at eksporten foregår innenfor regelverket betoner forhold som har lite å giøre med situasjonen i Jemen og koalisjonens faktiske handlinger. Norske myndigheter konkluderer i sin kommunikasion med Stortinget og den bredere offentligheten med at det ikke er risiko for misbruk av eksportert materiell fordi regelverket er strengt, fordi det ikke er bevis for involvering av norske våpen, fordi intervensjonen er lovlig, og fordi det eksporteres til nasjonalt selvforsvar. At norske myndigheter har eksportert også etter å ha anerkjent risiko for bruk av norsk materiell i Jemen, understreker bare den uunngåelige slutningen: Norske myndigheter legger ikke i stor nok grad risikovurderinger basert på reelle risikofaktorer (for eksempel mottakerlandenes humanitærrettsbrudd og historikk vedrørende avledning av materiell til Jemen) til grunn for beslutningene.

Det er et tankekors at en lignende type praksis - nemlig betoningen av andre forhold enn de som faktisk skal ligge til grunn for risikovurderingen - felte britiske myndigheter i retten i 2019, etter at Campaign Against the Arms Trade gikk rettens vei for å stanse våpeneksporten til Saudi-Arabia. Under rettssakene mot britiske myndigheter ble det klart at myndighetene, $i$ beslutningen om å tillate videre våpenleveranser til Saudi-Arabia under krigen i Jemen, i stor grad hadde unnlatt å vektlegge bevisene på humanitærrettsbrudd i Jemen. I stedet hadde forsikringer fra Saudi-Arabia samt "hemmelige» bevis fra etterretningshold blitt tillagt avgjørende vekt når beslutninger om å utstede eksportlisenser ble tatt, noe retten mente brøt med både britisk offentlig rett og EUs felles posisjon (Court of Appeal, 2019).

Resonnementet over leder til artikkelens andre konklusjon: Legitimeringen av eksporten til koalisjonslandene hviler på en tidvis feilaktig fortolkning av retningslinjene for våpeneksporten. Denne artikkelens datagrunnlag gir ikke holdepunkter for å konkludere med at den diskutable regelverksanvendelsen og videreføringen av eksporten fullt ut er drevet av industri- og markedshensyn, men man kommer heller 
ikke unna at den observerte implementeringen av retningslinjene for eksportkontrollen gir betydelig rom for å hensynta eksportinteresser.

«Skampåføring» anses - i mangel på hardere juridiske virkemidler - som en viktig mekanisme for å stille stater til ansvar for sin våpeneksport. Skampåføring har hatt en viss betydning i regjeringens eksportlinje til landene som kriger i Jemen. Myndighetenes manøvrering i spørsmål om eksport til land i koalisjonen har gjennomgående vist at man har gitt etter først etter massivt press fra media og Stortinget. Det hadde bygd seg opp et enormt press rundt de ansvarlige myndigheter i forkant av stansen i eksport av A-materiell til Emiratene i desember 2017 og B- og flerbruksmateriell til Saudi-Arabia i november 2018. Det ble stadig vanskeligere å forsvare eksporten, og stans i eksporten bidro begge gangene til å stilne styrken i kritikken. At salg av B-materiell og militært flerbruksmateriell fortsetter, vitner likevel om at «skampåføring» ikke evner å stanse all eksporten, men kun den mest graverende og kontroversielle delen av den.

Denne artikkelen bidrar til vår kunnskap om i hvilken grad og på hvilke måter reglene for eksportkontrollen implementeres. Med klare paralleller mellom norske og britiske myndigheters bruk av forsikringer, ser man særlig konturene av at retoriske krumspring som forsikringer og utelatelse er sentrale verktøy i legitimering av kontroversielle våpensalg. Her ligger helt klart et stort potensial for videre, komparativ forskning.

Artikkelens funn underbygger det flere i den norske offentlighet de senere år har påpekt: Norges våpeneksport til land som kriger i Jemen ser ut til å være på kollisjonskurs med regelverkene for våpeneksportkontrollen, både de internasjonale avtalene og de nasjonale retningslinjene (Egeland, 2019; Hellestveit, 2021, s. 248; Hoel, 2017, 2021; NIM, 2018; Redd Barna \& Changemaker, 2020; Riksrevisjonen, 2021). Kritikere har også kommentert at det ikke tar seg ut at regjeringen med den ene hånden støtter internasjonalt fredsarbeid, og med den andre hånden eksporterer våpen til land som har gjort seg skyldige i humanitærrettsbrudd i Jemen (e.g. Hoel, 2021; Redd Barna \& Changemaker, 2020). For Norges del kommer man dessuten vanskelig unna at en utenrikspolitisk profilering som fredsnasjon (Skånland, 2009) står i et nokså ubehagelig forhold til en samtidig vedvarende eksport til koalisjonslandene.

\section{Om forfatteren}

Susanne Therese Hansen har doktorgrad i statsvitenskap fra Norges teknisknaturvitenskapelige universitet (2016), og er forsker ved NTNU Samfunnsforskning. Arbeidet med denne artikkelen ble gjennomført under hennes postdoktorstilling ved Institutt for sosiologi og statsvitenskap, Norges teknisk-naturvitenskapelige universitet.

\section{Referanser}

Amnesty International. (2019). When arms go astray. Yemen's deadly new threat of arms diversion to militias (Rapport). Amnesty International.

Béraud-Sudreau, L. (2018). French arms exports: The business of sovereignty. Adelphi Series, 58 (175-476). https://www.tandfonline.com/toc/tadl20/58/475-476 


\section{Susanne Therese Hansen}

Bitzinger, R. A. (1994). The globalization of the arms industry: The next proliferation challenge. International Security, 19(2), 170-198.

Blanton, S. L. (2005). Foreign policy in transition? Human rights, democracy, and U.S. arms exports. International Studies Quarterly, 49(4), 647-667.

Brian, T. (2021, 18. mars). Can European arms companies be held liable for war crimes in Yemen? The New Arab. https:/english.alaraby.co.uk/analysis/how-european-arms-companies-are-aiding-yemens-war-crimes

Cooper, N. (2000). Arms exports, new labour and the pariah agenda. Contemporary Security Policy, 21(3), 54-77.

Court of Appeal. (2019). Dom i Campaign Against the Arms Trade vs. Secretary of State for International Trade. Sak nr. TS/2017/2079, 20. juni.

Dorman, A., Uttley, M. \&Wilkinson, B. (2015). A benefit, not a burden. The security, economic and strategic value of Britain's defence industry. http://www.defencesynergia.co.uk/wp-content/uploads/2015/04/A-benefit-not-aburden.pdf

Eisenträger, S. \& Foss, A. B. (2016, 6. januar). Anklages for delaktighet i krigsforbrytelser i Jemen. Norge eksporterte militært materiell for 733 millioner til Saudi-Arabia. VG. https://www.vg.no/nyheter/utenriks/i/ 1PJMM/anklages-for-delaktighet-i-krigsforbrytelser-i-jemen-norge-eksporterte-militaert-materiell-for733-millioner-til-saudi-arabia

Egeland, K. (2019). Hvorfor regelverket for våpeneksport ikke fungerer - og hvordan det kan fikses. Samtiden, $1,104-109$.

Eksportkontrolloven. (1987). Lov om kontroll med eksport av strategiske varer, tjenester og teknologim.v. (LOV-198712-18-93). Lovdata. https://ovdata.no/lov/1987-12-18-93

Eksportkontrollseksjonen. (2021). Personlig e-postkorrespondanse med artikkelforfatter. Mai-juni 2021.

Erickson, J. L. (2013). Market imperative meets normative power: Human rights and European arms transfer policy. European fournal of International Relations, 19(2), 209-234.

Erickson, J. L. (2015). Leveling the playing field: Cost diffusion and the promotion of "responsible" arms export norms. International Studies Perspectives, 18(3), 323-342.

FN. (2014). The arms trade treaty. https://thearmstradetreaty.org/hyper-images/file/ATT_English/ATT_English. pdf?templateId $=137253$

FNs ekspertpanel for Jemen. (2016). Final report of the Panel of Experts on Yemen established pursuant to Security Council resolution 2140. S/2018/192. https://www.undocs.org/S/2018/192

FNs ekspertpanel for Jemen. (2017). Final report of the Panel of Experts in accordance with paragraph 6 of resolution 2266. S/2018/193. https://www.undocs.org/S/2018/193

FNs ekspertpanel for Jemen. (2019). Final report of the Panel of Experts on Yemen. S/2019/83. https://undocs.org/ en/S/2019/83

FNs ekspertpanel for Jemen. (2020). Situation of human rights in Yemen, including violations and abuses since September 2014. A/HRC/45/CRP.7. https://www.ohchr.org/Documents/HRBodies/HRCouncil/GEE-Yemen/ A-HRC-45-CRP.7-en.pdf

Gjerde, R. \& Lom, J. A. G. (2021, 2. mai). Hemmeligstemplet dokument: UD tillot våpeneksport selv om mottakerland brøt folkeretten. Aftenposten. https:/www.aftenposten.no/norge/politikk/i/M31M0r/ hemmeligstemplet-dokument-ud-tillot-vaapeneksport-til-emiratene-selv-o

Hansen, S. T. \& Marsh, N. (2015). Normative power and organized hypocrisy: European Union member states' arms export to Libya. European Security, 24(2), 264-286.

Hansen, S. T. (2016). Taking ambiguity seriously: Explaining the indeterminacy of the European Union conventional arms export control regime. European fournal of International Relations, 22(1), 192-216.

Hattrem, T. (2016, 7. januar). Tendensiøst om norsk eksport av forsvarsmateriell. Dagbladet.

Hellestveit, C. (2021). Ulykkelige Arabia.Verden etter femen. Spartacus.

Hoel, D. (2017). Fred er ei det beste. Fra innsiden av den norske ammunisjonsindustrien. Spartacus.

Hoel, D. (2021, 6. februar). Hemmelig våpenkremmeri. Klassekampen.

Innst. 35 S (1967-1968). Innstilling fra utenriks- og konstitusjonskomitéen om forslag fra representanten Finn Gustavsen fremsatt $i$ Stortingets møte den 13. oktober 1967. https://www.stortinget.no/no/Saker-og-publikasjoner/ Stortingsforhandlinger/Lesevisning/?p=1967-68\&paid=6\&wid=a\&psid=DIVL1430\&pgid=a_0067\&s=True

Innst. 185 S (2015-2016). Innstilling fra utenriks- og forsvarskomiteen om nasjonal forsvarsindustriell strategi. https:/www.stortinget.no/no/Saker-og-publikasjoner/Publikasjoner/Innstillinger/Stortinget/2015-2016/ inns-201516-185/?lvl=0

Innst. 213 S (2015-2016). Innstilling fra kontroll- og konstitusjonskomiteen om sak om salg av brukt og utrangert forsvarsmateriell. https:/www.stortinget.no/no/Saker-og-publikasjoner/Publikasjoner/Innstillinger/ Stortinget/2015-2016/inns-201516-213/?lvl=0 


\section{Legitimering mellom normer og interesser}

Innst. 104 S (2017-2018). Innstilling til Stortinget fra utenriks- og forsvarskomiteen. Dokument 8:22 S.

Innst. 105 S (2017-2018). Innstilling fra utenriks- og forsvarskomiteen om Eksport av forsvarsmateriell fra Norge $i$ 2017, eksportkontroll og internasjonalt ikke-spredningssamarbeid. https://www.stortinget.no/no/Saker-ogpublikasjoner/Publikasjoner/Innstillinger/Stortinget/2017-2018/inns-201718-105s/?all=true

Innst. 81 S (2018-2019). Innstilling frå utenriks- og forsvarskomiteen om Eksport av forsvarsmateriell fra Norge $i$ 2017, eksportkontroll og internasjonalt ikke-spredningssamarbeid. https:/www.stortinget.no/no/Saker-ogpublikasjoner/Publikasjoner/Innstillinger/Stortinget/2018-2019/inns-201819-081s/?all=true

Johnson, R. A. I. \& Williardson, S. L. (2018). Human rights and democratic arms transfers. Rhetoric versus reality with different types of major weapons systems. International Studies Quarterly, 62(2), 453-464.

Liges des Droits Humains. (2018, 22 oktober). Ventes d'armes à l'Arabie saoudite: une décision immorale et irresponsable du gouvernement wallon. https://www.liguedh.be/ventes-darmes-a-larabie-saoudite-une-decision-immoraleet-irresponsable-du-gouvernement-wallon/

Lustgarten, L. (2020). Law and the arms trade. Weapons, blood and rules. Hart Publishing.

Markwica, R. (2018). Emotional choices. Oxford University Press.

Meld. St. 9 (2015-2016). Nasjonal forsvarsindustriell strategi. Forsvarsdepartementet. https://www.regjeringen. no/no/dokumenter/meld.-st.-9-20152016/id2459606/

Meld. St. 36 (2015-2016). Eksport av forsvarsmateriell fra Norge $i$ 2015, eksportkontroll og internasjonalt ikke-spredningssamarbeid. Utenriksdepartementet. https:/www.regjeringen.no/no/dokumenter/meld.-st.-3620152016/id2503422/

Meld. St. 5 (2017-2018). Eksport av forsvarsmateriell fra Norge $i$ 2016, eksportkontroll og internasjonalt ikke-spredningssamarbeid. Utenriksdepartementet. https://www.regjeringen.no/no/dokumenter/meld.-st.-520172018/id2576728/

Meld. St. 19 (2017-2018). Eksport av forsvarsmateriell fra Norge i 2017, eksportkontroll og internasjonalt ikke-spredningssamarbeid. Utenriksdepartementet. https://www.regjeringen.no/no/dokumenter/meld.-st.-1920172018/id2605358/

Meld. St. 26 (2018-2019). Eksport av forsvarsmateriell fra Norge $i$ 2018, eksportkontroll og internasjonalt ikke-spredningssamarbeid. Utenriksdepartementet. https://www.regjeringen.no/no/dokumenter/meld.-st.-2620182019/id2653741/

Meld. St. 25 (2019-2020). Eksport av forsvarsmateriell fra Norge i 2019, eksportkontroll og internasjonalt ikke-spredningssamarbeid.Utenriksdepartementet.https://www.regjeringen.no/no/dokumenter/meld.-st.-2520192020/id2706092/

Meld. St. 35 (2020-2021). Eksport av forsvarsmateriell fra Norge $i$ 2020, eksportkontroll og internasjonalt ikke-spredningssamarbeid.Utenriksdepartementet.https:/www.regjeringen.no/no/dokumenter/meld.-st.-3520202021/id2860232/

NIM. (2018). Innspill til Meld. St. 19 [2017-2018] Eksport av forsvarsmateriell fra Norge i 2017, eksportkontroll og internasjonalt ikke-spredningssamarbeid. https:/www.nhri.no/wp-content/uploads/2018/11/ V\%C3\%A5peneksport-3-nov-2018.pdf

Redd Barna \& Changemaker. (2020). Våpeneksport og krigen i femen. Utilstrekkelige risikovurderinger og svakheter i norsk regelverk. Rapport. https://changemaker.no/uploads/files/CMogRB_vaapenrapport_2020.pdf

Riksrevisjonen. (2020, 23. november). Avgradering av innhold $i$ hovedanalyserapport om myndighetenes arbeid med eksportkontroll av strategiske varer [Brev til Utenriksdepartementet].

Riksrevisjonen. (2021). Riksrevisjonens undersøkelse av myndighetenes arbeid med eksportkontroll av strategiske varer (Dokument 3:4).https:/www.riksrevisjonen.no/globalassets/rapporter/no-2020-2021/myndighetenesarbeid-med-eksportkontroll-av-strategiske-varer.pdf

Rådet for Den europeiske union. (2008). Council common position 2008/944/CFSP. https://eur-lex.europa.eu/ LexUriServ/LexUriServ.do?uri=OJ:L:2008:335:0099:0103:en:PDF

Rådet for Den europeiske union. (2019). User's guide to council common position 2008/944/CFSP. https://www. consilium.europa.eu/media/40659/st12189-en19.pdf

Schedler, J. (2012). Judgment and measurement in political science. Perspectives on Politics, 10(1), 21-36.

Secretary of State for Business, Innovation and Skills. (2016). Open skeleton argument of the Secretary of State for hearing 7, 8, 10 February 2017, i CAAT vs Secretary of State. Sak nr. CO/1306/2016.

SIPRI. (2021). Trends in international arms transfers, 2020. https://www.sipri.org/publications/2021/sipri-factsheets/trends-international-arms-transfers-2020

Skånland, Ø. H. (2009). Norsk utenrikspolitikk i fredens tegn: En diskursanalyse. Internasjonal Politikk, 67(3), 321-348.

Snyder, J. (2020). Backlash against human rights shaming: Emotions in groups. International Theory, 12, 109-132. 


\section{Susanne Therese Hansen}

Stavrianakis, A. (2017). Playing with words while Yemen burns. Managing criticism of UK arms sales to Saudi Arabia. Global Policy, 8(4), 563-568.

Stavrianakis, A. (2020). Requiem for risk: Non-knowledge and domination in the governance of weapons circulation. International Political Sociology, 14(1), 233-251.

Stohl, R. (2008). Questionable reward: Arms sales and the war on terrorism. Arms Control Association. https:// www.armscontrol.org/act/2008-01/features/questionable-reward-arms-sales-war-terrorism

Stortinget. (2017a). Møte i Stortinget 14. desember. Stortingstidende Nr. 31, Sesjonen 2017-2018.

Stortinget. (2017b). Skriftlig spørsmål fra Bård Vegar Solhjell (SV) til utenriksministeren. 22. august. Dokument nr. 15:1503 (2016-2017).

Stortinget. (2017c). Skriftlig spørsmål fra Audun Lysbakken (SV) til utenriksministeren. 8. desember. Dokument nr. 15:493 (2017-2018).

Søreide, I. E. (2018a). Debatt i Stortinget 1. mars. Stortingstidende Nr. 52, Sesjonen 2017-2018.

Søreide, I. E. (2018b). Svar på spørsmål om eksport av forsvarsmateriell til Saudi-Arabia. https://www.regjeringen. no/no/aktuelt/svar_eksport2/id2619791/

Søreide, I. E. (2019). Debatt i Stortinget 8. januar. Stortingstidende Nr. 37, Sesjonen 2018-2019.

Søreide, I. E. (2021a). Brev til Stortinget ved Kontroll- og konstitusjonskomiteen. Vedlegg 4 til Innst. 396 S, 2020 2021.

Søreide, I. E. (2021b). Feil om kontroll av våpeneksport. https://www.regjeringen.no/no/aktuelt/feil_om_eksport/ id $2847505 /$

TU. (2011, 28. januar). Mener våpen blir den nye oljen. https://www.tu.no/artikler/industri-mener-vapen-blirden-nye-oljen/248452

Utenriksdepartementet. (2016, 3. oktober). Femen og fakta om eksport av norsk forsvarsmateriell. https://www. regjeringen.no/no/aktuelt/jemen_eksport/id2513532/

Utenriksdepartementet. (2018a, 3. januar). Suspensjon av eksportlisenser til De forente arabiske emirater. https:// www.regjeringen.no/no/aktuelt/suspensjon_lisens/id2583359/

Utenriksdepartementet. (2018b, 3. desember). Svar på spørsmål om krigsmateriell og konflikten $i$ femen. https:// www.regjeringen.no/no/aktuelt/svar_jemen2/id2621228/

Utenriksdepartementet. (2021a, 2. februar). Riksrevisjonens undersøkelse av Utenriksdepartementets arbeid med eksportkontroll av strategiske varer i 2016-2018. https://www.regjeringen.no/no/aktuelt/rr eksportkontroll/id2831040/

Utenriksdepartementet. (2021b). Statsrådens svar. Vedlegg 2 til Riksrevisjonens undersøkelse av myndighetenes arbeid med eksportkontroll av strategiske varer, Dokument 3:4 (2021-2021). https://www.riksrevisjonen.no/ globalassets/rapporter/no-2020-2021/myndighetenes-arbeid-med-eksportkontroll-av-strategiske-varer. pdf

Wearing, D. (2016). A shameful relationship. UK complicity in Saudi state violence (Rapport). Campaign Against the Arms Trade.

Wicken, O. (1992). Moralens vokter eller våpenkremmer? Forsvarsstudier, 3.

\section{Abstract in English \\ Legitimation between norms and interests. Norway's arms exports to countries at war in Yemen}

Norway is internationally obliged to abstain from arms exports in the presence of an overriding risk that the exported equipment can be used in international humanitarian law violations. In addition, Norwegian national decisions state that Norway should not export weapons to warring countries without the export being motivated by security policy, particularly alliance considerations. Nevertheless, Norway's arms exports to several countries in the Saudi Arabia-led coalition persisted during the war in Yemen; a coalition that has committed numerous humanitarian law violations in Yemen, and to which Norway exports on a commercial basis. This article examines how the Norwegian government has legitimized its arms exports to countries in the coalition. 
The article finds that the government's legitimation is constructed around five dimensions, four of which take the form of publicly communicated reassurances that the government is in full control and follows the regulations. A fifth dimension, deliberately omitted and not communicated by the government, but visible in leaked sources, contains concerns that stopping exports could damage the defence industry's market opportunities in the region. The article's conclusion is twofold: First, the combination of reassurances and omissions shows that the legitimation is largely intended to reassure critics. Secondly, the content of the legitimation shows that exports are based on sometimes incorrect interpretations of the guidelines for arms exports.

Keywords: legitimation - arms export • norms • defence industry • international humanitarian law 